David F. Lancy

"First You Must Master Pain:” The Nature and Purpose of Apprenticeship

David.Lancy@USU.EDU

Program in Anthropology

Utah State University

Logan, UT, 84322

\begin{abstract}
The goal of this study is to distill from a large body of literature on children learning crafts, such as pottery and weaving, the characteristics of apprenticeship as a distinct phenomenon. Currently apprenticeship is considered indistinguishable from other, more informal, means of skill transmission. From the literature survey, eleven attributes are identified as belonging to the archetypal apprenticeship. The analysis then advances to consider the genesis or raison d'etre for the apprenticeship. The argument is advanced that the apprenticeship is designed to simultaneously train novices in specific craft or trade skills while socializing them to join the social and cultural elite represented by master craftsmen. The article concludes by considering the role of apprenticeship in the evolution of schooling. Apprenticeship, formal versus informal education, crafts, ethnology.

Introduction $^{1}$
\end{abstract}


Apprenticeship has attracted the interest of cultural anthropologists as well as archaeologists (Coy 1989a; Crown 2002; Singleton 1998a) and historians (De Munck and Soly 2007). Coy, for example, claims that "...apprenticeship has figured significantly in the evolution of work and the social division of labor (Coy 1989b:xi)." However the analysis of this material has been limited and the nature and purpose of apprenticeship remains somewhat obscure. Analysis has been hampered by two primary problems. Scholars tend to focus on describing individual cases of apprenticeship with little comparative analysis. The available surveys include relatively few cases (e.g. Coy 1989c; DeCoker 1998). The second problem is that apprenticeship researchers usually fail to distinguish between apprenticeship and other, similar but informal means of acquiring craft expertise. In the introduction to an edited volume containing ethnographic studies of apprenticeship, the editor makes clear that he's using "apprenticeship" in an extremely broad sense to cover any situation where a novice learns from someone who's more expert (Singleton 1998b:6; see also Gamst 1989:65). Hence, no attempt has yet been made to conduct a broad survey of the literature on apprenticeship with the goal of isolating the characteristics that set this phenomenon apart from other modes of learning complex skill sets. And, as a logical corollary, we do not have an analysis of the genesis or purpose of the apprenticeship in the specific or general case.

In spite of the fact that there is a corpus of material to draw on (Table 1), apprenticeship is a challenging topic to pursue. The first difficulty is that, as just indicated, there has been a tendency to blur the distinction between acquiring a skilled trade through an apprenticeship and through more informal means. An earlier survey (Lancy 1996) was drawn on to critique the dichotomy proposed (e.g. Greenfield and Lave 1982) between the informal education of children in the village versus the more formal processes observed in the classroom. I argued then that apprenticeship represented an 
instance (along with adolescent initiation rites) of formal education in the village in that many aspects were governed by unvarying and near sacred (formal) practices (Lancy 1996:176-177). But it is also true that many of the learning processes inherent in the apprenticeship can be found distributed widely in the general learning environment of pre-modern societies without schools (Lancy 1996; 2008; 2012; Lancy and Grove 2011). I will, therefore, begin with a review of informal learning of crafts to establish the foundation on which apprenticeship is built.

Another difficulty that an ethnologist faces is that there is rarely a unique term in the vernacular that corresponds to "apprenticeship." Indeed, the term only appears in English texts from the $17^{\text {th }}$ century onward. In Marchand's comprehensive study of "apprenticeship" in Yemen, he freely acknowledges that there is no native term to describe the phenomenon (Marchand 2001:156). On the other hand, many contemporary western writers on pedagogy (e.g. Gruber and Mandl. 2001:602-3) use the term to describe a relationship between teacher and pupil that does not even remotely resemble the master/apprentice relationship observed by anthropologists. Indeed, anthropologists consistently choose not to define apprenticeship but, instead, describe it as a conglomerate of discrete components (Coy 1989c:1-4). Another challenge arises because of significant changes in the nature of apprenticeship in Europe and, especially, Germany. Evolving labor and child protection laws from the late $19^{\text {th }}$ century to the present have enhanced the rights and opportunities of the apprentice creating a process now better understood as "vocational education" (Mortimer and Krüguer 2000:479).

In spite of the fact that the term "apprenticeship" cannot give us a reliable basis for searching the literature, I believe that there are unique attributes of the apprenticeship that permit the construction 
of a workable definition. For this analysis, apprenticeship will be defined as a formal, contractual relationship between a master and a novice of a specific duration which is designed to serve two ends: to provide cheap labor (by the apprentice, Stella 2000:31) and/or fees to support the master's enterprise and; to afford the apprentice an opportunity to learn and receive certification for mastery. This definition guided my search through the literature for cases of apprenticeship. From this review and analysis, I was able to identify additional attributes consistently found associated with apprenticeship. Eleven attributes are identified and delineated ranging from the co-residence of the apprentice and master to the use of harsh means to discipline and correct the apprentice.

Once the analysis of the "what" question is complete, I will move on to the "why" question. Isolating the attributes common to apprenticeship permits at least some speculation about the circumstances that may have given rise to this phenomenon. Briefly, I will argue that apprenticeship is designed to resolve a paradox (Graves 1989:52-53). Master craftsmen own knowledge and skill of great value. Hausa weaver/farmers are much better off, financially than those who only farm (Defeanbaugh 1989:164), for example. Further, craft workshops represent (in contemporary parlance) "Hot Spots" of gossip and social interaction. The Master craftsman gains not only wealth from his craft but political clout and prestige as well as, in many cases, formal ritualistic authority (Lancy 1996). It is certainly in the community's interest as well as in the interest of the aspirant craftsperson to continue these valuable trades and broader traditions. But, in transmitting this commoditized knowledge to a young outsider, the Master and his/her fellow elite are placing themselves in jeopardy. The apprentice threatens their livelihoods as an eventual competitor but also by his/her behavior, public standing, adherence to tradition, respect for the master and progress or 
lack thereof. Apprenticeship, therefore, is structured very carefully to train the apprentice while simultaneously exerting very tight control over his/her behavior in the present and in the future.

\section{Methodological Issues}

The methodology used involves canvassing the ethnographic record, assembling illustrative cases and, teasing out broad patterns. Two primary strategies were employed to locate relevant cases: searching the HRAF data base of ethnographic reports ${ }^{2}$ and; mining the bibliographic information in the (un)published literature. That is, the literature review in a given study of crafts learning would lead me to others not yet in my corpus. This search for relevant cases, followed by comparison and contrast to elucidate patterns is referred to as ethnology (Voget 1975). My approach parallels that of MacDonald who describes her review of the ethnographic record on learning to hunt as a "crosscultural synthesis" providing an analysis that is, of necessity, "qualitative, as the relevant evidence from the ethnographic literature is either anecdotal or generalized and includes limited quantitative data (MacDonald 2007:390)." This particular survey follows on a comprehensive review of the ethnographic and historic records pertaining to childhood and youth (Lancy 2008) and more focused reviews on teaching and learning (Lancy 2010) and learning to work (Lancy 2012). In those reviews, approximately 1700 published and unpublished reports have been used. ${ }^{3}$

\section{Table 1: Cases Examined in the Survey ${ }^{4}$ (found at end of paper)}

Approximately seventy cases are drawn on in my survey (Table 1). The majority of the cases represent detailed ethnographic descriptions of young people learning to master a craft including weaving, pottery, blacksmithing and wood-working among others. In several cases (Cooper 1989; Coy 1989d; McNaughton 1988; Tanon 1994) the ethnographer served an apprenticeship, becoming a 
participant observer. Roughly ten sources are secondary, representing surveys of the historic or ethnographic records. ${ }^{5}$ The goal of this survey is to identify the components or attributes of the typical apprenticeship. These individual attributes can then be combined to create an archetypal apprenticeship. This archetype should apply regardless of geography or the particular craft being transmitted.

Descriptions range from monograph-length (McNaughton 1988) to fairly brief treatments in an article devoted to only a limited aspect of apprenticeship (e.g. Marguerat 2000). The most thorough studies (Jordan 1998; Marchand 2001; McNaughton 1988; Singleton 1989; and others) give me a firm foundation but the (more numerous) fragmentary accounts are useful in extending the range and variety of cases and also to test the archetype. Deviations from the archetype (e.g. female apprentices, cf. Wallaert 2008, companionable relations between master and apprentice Stout 2002) are noted throughout the analysis.

\section{The Play Stage as Precursor to the Apprenticeship}

First, I would note the fundamental "staged" character of virtually all work in traditional society affording a graded curriculum for the novice to gradually move through (Lancy 2012). While we may be familiar with terms like apprentice, journeyman and master, children embark on a trade well before these named levels of mastery apply and in more informal contexts than the apprenticeship proper. In Becoming a blacksmith in Gbarngasukwelle (Lancy 1980), I described children's amazingly detailed and faithful replication of the Kpelle blacksmith's forge in an episode of makebelieve. The blacksmith's compound was a hive of social activity in the village, consistently 
attracting a crowd of enthralled spectators and gossips, young and old (also true in a Kuba village, cf, Binkley 2006:106). Children could watch the action of the smiths and eavesdrop as village affairs were retailed. They thus built up a stock of script material that could be woven into their makebelieve play. The boy playing the smith, in particular, had, obviously absorbed a great deal of the processes, both technical — he constructed reasonable replicas of bellows, anvil, tongs and socialassigning the roles of novice, wives and helpers to his playmates. The terminology for tools, actions and relationships used in the "script" was also a faithful rendition. Because most work, including skilled work, is public, children will be willing spectators and, then, imitators. This extended example can be supported by many others (Bowser and Patton 2008:110; Campbell 1964:156; Jenness 1922:219; McClendon and Holland 1979: 108; Tanon 1994:34) of children replicating adult work activity — especially crafts—in play. The archaeological record is also a rich source of material indicating that children were encouraged to play with the skill sets they might eventually attempt to master as crafts-persons (Dawe 1997; De Lucia 2010; Lipsett-Rivera 2002; Park 2006; Smith 2006). Collectively, these cases suggest a play stage in the acquisition of crafts. As Greenfield, for example, notes of Zinacantecan weavers, the majority, when small, had done play weaving on a toy loom constructed for them (Greenfield 2004:37).

As essential as this play stage may be in learning adult tasks, no one would suggest that the child at play is an "apprentice," he or she is "just a child." At most, someone might recall, when the older youth is presented as a candidate for apprenticeship, that they were ardent in their play pursuit of blacksmithing or weaving and take this as a positive omen.

\section{Learning Crafts in Informal Settings}


While apprenticeship is fairly widespread cross-culturally, it is by no means universal. Further, in a given society, formal apprenticeship may only be provided for one or two crafts or skill suites. This means that most traditional "education" for subsistence and craftwork is informal. Even complex crafts like weaving (Bolin 2006:99), pottery (Crown 1999:29) or mat-making (Lancy 1996:153-154) may be learned largely in the absence of any explicit lesson or teaching. The following anecdote is representative of much of this literature:

A [Chiga] girl will...take up the art of weaving baskets when and as it pleases her to do so. Her mother or sister will...never say, "Make it tighter," or "Set the awl higher"...they will not slow down the process or guide her hand. Should the beginner find the process discouraging and the trials unsatisfactory, she may abandon the whole effort, to renew it again at some later date, or perhaps to forget it altogether [Edel 1996:179].

Not only are there numerous examples of children learning crafts without instruction, I found cases (including in my own field work-Lancy 1996:151) in which the aspirant craftsperson seeks out an expert for instruction, in effect, bidding to become an apprentice, and is rebuffed (see also MacKenzie 1991:102; Pope-Edwards 2005:91; Reichard 1934:38,41). In folk theories of children's learning and development there is the idea that, to learn a craft, the individual must be highly motivated and be willing to proceed towards mastery largely on their own. Nevertheless, across the ethnographic record, there is considerable variability ranging along a continuum from self-taught, completely informal skill acquisition to guided, somewhat formal transmission. Even at the most formal end of the continuum, however, relationships are based on the norms of kinship, not 
instruction and the process is described as "helping" or "getting help" rather than teaching (Gosselain 2008:160-161; Lancy 2010).

Whether or not adult experts make themselves available to potential novices depends on how critical the particular skill set is to successful adaptation in the society (Chernela 2008). In an Andean village all girls must learn to weave and "women frequently reported learning from their mothers, grandmothers or other female relative (Sharratt 2008:1, see also Laczko 1979:137)." Where the skill is critical a parent or other kinsman will allow the youngster to carefully observe craft production (MacKenzie 1991:100) as long as they remain unobtrusive. Children are permitted to practice with extra or cast-off materials (Baxter 2005: 54; Huang 2009:85). Their fledgling efforts may be critiqued (Silva 2008:235). When they feel the child has shown appropriate motivation and level of maturity, the expert may incorporate the child's efforts into their own production, giving them a bowl to paint or taking one they've shaped and painting it for them (Bowser and Patton 2008). The expert may intervene, strategically, when the child gets "stuck" at a difficult part (Wilbert 1976:323). However, no matter how eager and competent the novice craftsperson, the expert remains focused on his or her own production not on the novice (Köhler 2012).

We have then a large number of cases of children acquiring craft expertise in contexts ranging across a continuum of informality. The cases lack many of the attributes of the archetypal apprenticeship to be discussed shortly. And they are distributed very much in accord with the distribution found in the single quantitative survey available. Crown (2002) reviewed data from twenty-five pottery-making societies in the Human Relations Area Files (HRAF) and in roughly half the cases, "children learned pottery production by observation-imitation alone [as above], in twenty-four percent they received 
some verbal instruction from adults in domestic contexts [as above], and in twenty-eight percent they learned through more formal apprenticeships [as below] (Crown 2002:109)."

\section{Characteristics of the Apprenticeship}

My survey and analysis revealed eleven common attributes, which I will discuss in turn. These eleven attributes were common to the majority of cases.

\section{Cohort is Exclusive}

Much of children's work such as errand running, sibcare, herding, gardening — what I refer to as the chore curriculum (Lancy 2012) — is mandatory, undertaken by all children of appropriate age. Access to more complex or valued skills may be restricted. Boys are more likely to become apprentices than girls, in spite of the fact that girls may be more likely to practice crafts. Data from the Middle Ages in Europe suggest an imbalance of 10 to 90 percent (Alexandre-Bidon and Lett 1999: 85). There are probably a number of reasons for this including the threat to a girl's honor that may arise if she works outside the home. Indeed in the few cases of girls receiving formal instruction in a craft, it is still securely within the domestic perimeter (Silva 2008; Wallaert 2008).

Crafts, including those for which an apprenticeship is required, may be strictly gendered. "In Cameroon, women are potters, men blacksmiths (Wallaert 2001:473)." Among the Akwete only women may weave (Aronson 1989:151), the reverse is true for the Tukolor (Dilley 1989:185). Other barriers to craft participation may relate to clan membership (Spindel 1989: 71) or the family's 
social standing (Barron 2007:49). To become an apprentice "in a Kanõ atelier...membership in the samurai class was the normal prerequisite for entrance (Jordan 1998: 49)." Apprenticeship is reserved for crafts that earn the master craftsperson significant income and status so apprentices must meet appropriate selection criteria, including those just mentioned. Individual attributes may also figure in the selection process. For example, among the Anang, a boy is picked for training if he displays significant talent for woodcarving or seems “chosen” supernaturally (Messenger 1973:104). Considering that there are usually fees paid up front and that the child's labor is now lost to the family, it is in the family's economic interest to weigh carefully the decision to apprentice a child (Lloyd 1953: 38).

\section{Does Not Apprentice with Parent=Moves into Master's House}

It is uncommon for a child to apprentice with a parent or close kin (Bradley 1991: 109; Gies and Gies 1987:209; Herzfeld 1995:136-138). Preferentially, he will be apprenticed to a stranger or more distant kin (Coy 1989d:119). The reason most often given is that the parent cannot impose the strict discipline that is required. Esther Goody's characterization of Gonja weaving is representative.

In the Gonja weaving industry of Daboya, weavers' sons are sent as foster children to learn from a skilled weaver...When I asked why he wasn't teaching the boy himself, Bakweji curtly insisted that this wouldn't work. It would only lead to trouble between them...the son wouldn't give the father proper respect... [Goody 2006:254]. 
These examples from the ethnographic record can be augmented by historian's accounts of apprenticeship in pre-modern Europe indicating the rarity of "at home" apprenticeship (especially for boys). Further, while apprentices joined the master's household, their role was clearly not that of family member (Mitterauer and Sieder 1997:103-105) .

\section{Hierarchical Relationship between Master and Apprentice.}

The hierarchical relationship between master and apprentice is of paramount importance. ${ }^{7}$ It is constructed from the high standing and in loco parentis power of the master and the youth, lowstanding and incompetence of the apprentice. The role of apprentice has been compared to that of a bondsman or acolyte (Ghosh 1992:260). Additionally, the family must pay a fee or goods in kind to place their child with a master (Lloyd 1953:38; Moeran 1984:37). The master's knowledge is considered to have great worth and the apprentice trades his or her labor (Wallaert 2008:187-188) and obeisance (Jordan 1998:49) for access to that knowledge.

\section{Initially, Apprentice Does Menial Work}

At first the apprentice learns by observing the work of those more expert but is mostly occupied with menial chores such as fetching and cleaning up or simple, repetitive tasks like bobbin-winding (Dilley 1989:187) or bringing clay, water, or wood to the master (Wallaert 2008:188). The apprentice demonstrates through hard work and diligence, over a, sometimes lengthy, period his or her worthiness for instruction (Jordan 1998:49-50). Otherwise, why should a master waste time on an unpromising pupil? "Before the neophyte [Mande blacksmith] can master techniques and form, 
he has to master pain. He begins at the bellows, where he spends many hours each day (McNaughton 1988:24)." The same is true for more informal crafts acquisition but, compared to the apprentice (Cooper 1989: 144), the novice learning informally has much greater autonomy to progress at his/her own pace and move more quickly out of the menial stage.

\section{Tasks are Laddered or Staged in Difficulty}

Beyond the menial stage, most crafts or areas of work requiring an apprenticeship can be further broken into stages depending on the physical and intellectual challenges of the component tasks. The basic skill of weaving may be mastered early but it takes much longer to learn how to lay the warp, how to create designs, how to assemble the frame and how to plan for and purchase the necessary materials (Dilley 1989:187). This laddering facilitates the auto-didactic process. Novices can progress on their own with little need for guidance because each advance in skill is a "baby-step." The Japanese pottery apprenticeship incorporates five stages including a pre-pottery stage where menial tasks are carried out to prove one's dedication and ability to work and the last stage where the competent apprentice produces work that will be sold by the master as recompense (Singleton 1989:18-19). The "ladder" may be constructed from the varied product menu characteristic of the craft such as the tools produced by a Yoruba blacksmith:

He assisted...by pressing the bellows in the forge and by holding some of the equipment, while the blacksmith beat a piece of iron into shape. After he had watched the master do some work, the apprentice began to heat metal and to make small knives... The apprentice [next] learned how to make big knives and cutlasses when he reached the age of fifteen years, but by the time he 
became an adult (about twenty-one years of age), he had acquired highly technical skills to make instruments like hoes, traps, guns, lamps and umbrellas [Obidi 1995:376].

Note also that, in many cases, the apprentice is prevented from moving up the ladder for fear they will waste or damage costly materials. For example, Sternke (2010; see also Ferguson 2003) reports on an archaeological site in Ireland where novice tool-makers were evidently given cast-off or poor quality blanks to practice with. Another very clear instance is reported in Lave's study of a Monrovia tailor shop.

Production processes [in a tailor shop] have logic and order to them, and these shape apprentice learning activities...it is more costly to make an error when cutting out a garment than when sewing it. Apprentices learn to sew garments before learning to cut out garments....[they] work on small garments that can be made of scraps before items that take more, or more expensive fabrics... [they] start on simple garments and gradually move on to more complicated ones [Lave 1982:181-183].

\section{Little Active Teaching}

One of the most common findings by anthropologists studying children's acquisition of culture is the infrequency of teaching by adults. Rather, careful observation, imitation, trial and error and practice for improvement of skill and speed form the core pedagogy (Lancy 2010). This is true for apprenticeship as well. The master, even if it's the child's mother (Wallaert 2001:484), remains aloof and stern, urging the child to greater effort and greater attention to the model. In Japan the 
apprentice is minari-someone who learns from observation. The master potter will rebuke the apprentice for posing a question as the answer would have been clear had he been more observant (Singleton 1989:14, 26). In a Greek apprenticeship, questions by the apprentice are construed as a challenge to the master's authority (Herzfeld 1995:138).

The master is focused primarily on his or her own work and output, not the learner. So the Mande blacksmith does not stop working to guide or teach —reasoning that the apprentice should "discover his own mistakes (McNaughton 1988:28)." Intervention is rare and strategic—designed to assist the apprentice over the most difficult speed-bumps in the learning curve or prevent damage to material or equipment or both. Apprentice Dioula weavers are free to learn on their own as long as their errors can be readily corrected and they don't jeopardize the raw material. "In risky operations, such as the preparation of the warp, the expert takes over and the apprentice serves as observer-helper (Tanon 1994:36)." When the master stops to correct the apprentice, they eschew verbal instruction in favor of physically shaping the learner's limbs and movements (Fowler 1977:29).

\section{Prominent Use of Punishment and Abuse in Training Apprentices}

The interaction between master and apprentice is often harsh. Indeed, some of the earliest legal tracts relating to youth address violence by a master against an apprentice. Rawson discusses the case of a Roman shoemaker who strikes his apprentice with a shoe last, knocking out his eye. The action was considered justified on the basis that the intent was instructional (Rawson 2003:194). An apprentice from ancient Athens complains that he is "perishing from being whipped...tied up [and] treated like dirt (Golden 2003:14)." In medieval London the indentures an apprentice signed specified the rights 
of master and mistress to discipline the youth and beating was customary (Barron 2007:51; see also Steidl 2007:148). This attitude maintained the hierarchical relationship and insured that apprentices were highly motivated. But there is also the frequent suggestion in the literature that it was in the master's interest to extract manual labor from the apprentice, but then force him or her out before completion to avoid creating a new competitor.

Even in contemporary accounts, the use of verbal abuse is also consistently reported. Among minaret builders "curses and derogatory remarks were the most common form of communication from 'teacher' to 'learner'...As opposed to explanation....abuse served as a potent disciplinary tool, effectively reinforcing the existing hierarchy amongst the builders (Marchand 2001:144)." The apprentice Dii potter can expect to be punished and humiliated for any and all mistakes to insure public acknowledgement that the failure lies with the apprentice and not the master (Wallaert 2008:190-192). Typically implicit but sometimes quite explicit in the pedagogy of apprenticeship is the notion that skills learned easily, without stress or discomfort, are devalued.

\section{Originality Not Encouraged}

By and large, apprenticeship is a conservative force in society. Not only does it ratify the high standing of the older craftsperson, it reduces the likelihood of innovation. At an age when the apprentice might be in a risk-taking frame of mind, his or her behavior vis-à-vis the profession is tightly controlled. Hausa weaving apprentices must "copy the master's techniques...exactly (Defenbaugh 1989:73).” Apprentice Pomo basket-makers were given a limited repertoire of designs to follow, leaving more complex or unusual designs as the prerogative of more senior 
practioners (Pryor and Carr 1995:280). The hegemony of experts is also reflected in the "craft guilds of the Middle Ages [which] crippled individual initiative and rejected innovation as unfair competition (Mitterauer and Sieder 1997:104; see also Lloyd 1953: 37).”

As traditional societies are affected by the economic and technological changes associated with globalization, innovation and transition in crafts will occur. In one Iranian village, master weavers lack apprentices as their designs are considered old-fashioned (Friedl 1997:4). Elsewhere in Iran, new weavers are now free to learn from a variety of models-young and old (Tehrani and Collard 2009:289). Similarly, in Greenfield's longitudinal study of Mayan weavers, new markets for textiles have emancipated novice weavers who are now free to learn on their own and from a variety of experts (Greenfield 2004: 81). In Brian Moeran's study of the aesthetics of (Japanese) Onta pottery, his informants suggested that, in the distant past, before folk-craft pottery became collectable and economically important, there was greater harmony in the atelier and village and "master craftsmen looked after their apprentices (Moeran 1997:41).”

\section{The Master's Secrets and Lore}

One of the most interesting aspects of apprenticeship is the understanding that the master's expertise is at least partly due to his or her knowledge of secrets or lore and that this information is not willingly passed on to apprentices. Hence, the apprentice must use guile and cunning to "steal" this vital knowledge (Gladwin 1970:72; Herzfeld 1995:131; Jordan 1998:56; Marchand 2001:119). Indeed, he may hang on, continuing to work, gratis, in hopes of discovering vital clues (Bledsoe and Robey 1986:216). The Tukolor case is representative: 
The...[Tukolor] apprentice learns...not only the necessary skills in weaving...but also the mystical and religious aspects of craft lore [called gandal which] can be used...to protect the weaver from spiritual forces associated with the craft and...as a means of defense against the malicious intention of other...weavers [Dilley 1989:190,195].

\section{Apprenticeship is Lengthy and Not Always Successful}

The age at which an apprenticeship begins or ends varies widely but, in a number of cases, the apprentice may be as young as eight and completion may not be certified before the late teens. However, Kaplan questions "the primacy accorded to education in the apprenticeship process...earning matters more than learning (Kaplan 2007:207).” The master makes calculated judgments on how to get the most value from the apprentice. A competent apprentice may be held back as the proceeds from his work are retained (appropriately) by the master (Dilley 1989:189; Wallaert 2008:188). Coy argues that there is a trade-off between fees paid up front to secure a shorter apprenticeship versus the sweat equity inherent in a longer apprenticeship. (Coy 1989c:7)

In the majority of cases that I have examined, the completion rate is considered quite low and many researchers suggest that this is intentional. Many masters in Togo "deliberately withhold critical skills and information so that their 'released' apprentices will not be able to compete effectively (Marguerat 2000: 244)." A historical perspective reinforces this conclusion: 
Quantitative data indicate that a great many apprentices failed to complete their contract.

Between 1540 and 1590 nearly forty-five percent of the apprentices in the London cabinetmakers" guild were in fact listed as "gone" or "run away" ...In most cases, apprentices left because of ill treatment ...physical abuse, or because their master was unwilling to assign them anything other than demeaning tasks (which meant that they were taught nothing) [De Munck and Soly 2007:9; see also Stella 2000:26].

\section{Ends with a Graduation Ceremony}

Ceremony to mark the end of an apprenticeship is not commonly recorded in the literature but I suspect this has to do with the short-term observation window in the typical ethnography. That is, if the apprenticeship last five years or more while the ethnography lasts six months, the chances it will "capture" a graduation are slim. Given the cost, rigors, length and non-completion rate, it is likely that the successful craftsperson will be celebrated (Wallaert 2008:192), as among the Yoruba:

An apprentice [blacksmith] ended his apprenticeship with a ceremony ...the master poured a libation to the god of iron, who, according to Yoruba belief, would bless the new craftsman abundantly [Obidi 1995:378].

And it is certainly the case that, in more complex societies including Japan and medieval Europe, the completion of an apprenticeship is contractually acknowledged.

\section{Why is the Apprenticeship Necessary?}


In the following discussion, I will endeavor to elucidate the main reasons for the evolution or emergence of apprenticeship as a distinct institution, one found in societies as diverse as ancient Rome, the New Guinea Highlands (Langda adze-making) and contemporary Nigeria (Yoruba ironwork). To do this we must view apprenticeship through two lenses: pedagogy and sociology. From the perspective of pedagogy, apprenticeship does not appear so unique. The pedagogy of crafts acquisition includes, as we've seen: a play stage; observation of an expert at work and imitation by the novice; a laddered or staged sequence of sub-tasks; a great deal of trial and error; the demonstration of diligence and motivation on the novice's part to attract the attention of the expert and; little or no verbal instruction or even structured demonstration by the expert. This suite of characteristics can be found in both the informal transmission of crafts as well as the formal apprenticeship. This isomorphism helps us to understand why so many anthropologists who've focused on apprenticeship have considered it as just another variation on the village-based informal learning (versus schooling) pattern (Greenfield and Lave 1982; Singleton 1998). They have focused on the pedagogy of apprenticeship, ignoring the sociology.

It is the master's high standing that adds another dimension to apprenticeship which I refer to as sociology. There is, first, an economic aspect to the master's rank. Apprenticeship tends to be associated with more complex skill/valuable products vs. less complex skill/less valuable products, e.g. wheel-thrown (Singleton 1989) vs. coil-built pottery (Bowser and Patton 2008), superior vs. inferior quality stone beads (Roux et al 1995) and metal tools (Obidi 1995) vs. floor mats (Lancy 1996). Apprenticeship usually implies an expensive infrastructure such as the blacksmith's forge, a tailoring shop with sewing machines, a large complex loom for large-scale textiles, or, a potter's 
wheel and kiln. In Accra, “... a sewing-machine [is] a substantial capital investment which inhibits widespread entrance to the trade (Peil 1970:139)." Such expensive infrastructure precludes opportunities to "pick up" the craft without guidance.

It is probably also true that, even before the advent of external markets for local "art" craft products such as Navajo rugs and (Japanese) Onta pottery, the crafts transmitted via an apprenticeship were of considerable economic significance compared to other crafts. These workshops produced critical goods of a refined quality. It was, therefore very much in the economic interest of practioners to limit access to the craft, control the training to insure high, uniform standards and to limit competition. In more populous towns or cities with multiple practioners of particular crafts, we can expect them to band together in guilds (Lloyd 1953). Guilds, historically, served the masters' needs at the expense of the novice (Kaplan 2007; Mitterauer and Sieder 1997) Ethnographers and historians both stress the conservative nature of craft production when a formal apprenticeship is indicated. This suggests that these crafts-persons must expect stable market conditions with little demand for innovative products. Where change and innovation are the rule, novices learn informally from multiple experts rather than a single master.

Economics aside, the craft master usually commands political and religious expertise or spiritual power above the ordinary ${ }^{8}$. Indeed, many societies treat their most prized crafts as imbued with the divine. For example, among the Langda of Irian Jaya, “... because of the high value traditionally placed on stone adzes, a good deal of social control is exerted over the materials and skills needed to produce them (Stout 2002: 700).” Among the Kpelle, the blacksmith is inevitably a respected diviner and ritual specialist (Lancy 1996). In addition or, alternatively, the craft master may have high 
political standing or authority. Rolled together, high craft skill combined with spiritual and social potency usually signal the necessity for esoteric and/or cultural knowledge, of extra-human forces and folklore unique to the profession. To acquire this lore, and the high standing that it affords, the apprentice must bind himself to a master in a very formal apprenticeship. Apprenticeship for transmitting important adult skills other than crafts is not common. However, there are cases of apprenticeships to become a: traditional Kogi "priest" (Reichel-Dolmatoff 1976); Mende morimen ritual specialist (Bledsoe and Robey 1986); long-distance ocean navigator in the Carolines (Gladwin 1970) and; Hausa traveling minstrel (Ames 1973). These cases also show evidence for most of the eleven attributes just explicated but, more importantly, the master, in each case, is a very highly respected public figure.

Aside from the attributes shared with informal crafts learning (tasks are laddered, little active teaching), the eleven attributes I have identified as characteristic of the apprenticeship serve to select individuals and shape them into compliant members of an exalted profession. The process of socialization begins in the careful selection of the apprentice and the formal agreement, sealed with a fee or gifts. Where the informal crafts novice is free to abandon the pursuit (Edel 1996) the new apprentice is doubly obligated to the master and to his own family to conform to the demands of the apprenticeship. This commitment is reinforced by the requirement that the apprentice "board" with the master. Add in the master's complete control of the apprentice's life, his or her authority to assign menial work (unrelated to the craft) and the freedom to punish and verbally abuse the novice and we can see the outline of what Goffman (1961) referred to as a "total institution." This reality was acknowledged by Queen Elizabeth in 1590 in holding masters legally responsible for the behavior of apprentices and, in particular, their confinement during the nightly curfew (Beier 1978). 
Other signs of apprenticeship as a total institution include the somewhat elastic length and lack of assurance of completion. The apprentice's lack of autonomy to pursue particular avenues for his/her further development, such as assaying more challenging products—absent the master's approval— reinforces a psychological sense of dependency. The existence of important lore or "deep knowledge" that the apprentice is aware of but unable to access in any legitimate way can reinforce a sense of commitment and loyalty. In short, the socialization goals of apprenticeship (and of many total institutions, including the military and prisons) are almost synonymous with the "Bush School" or adolescent initiation rite and, as I have argued previously, the primary purpose of the Bush School is indoctrination (Lancy 1975).

Apprenticeship solves a practical problem, namely, how can those whose high social standing and wealth stem from the mastery of a relatively scarce and valued trade transmit their knowledge and skill to the rising generation without at the same time exposing themselves to the reputation and income-reducing effects of potentially irascible youths in their midst? We see in the pedagogy of apprenticeship well established practices that serve effectively to transmit the entire cultural repertoire down the generations. The socialization practices found in apprenticeship add a number of attributes to the mix and are designed to carefully integrate the youth into a closed fraternity or, failing that, to eject and effectively bar the failed aspirant.

\section{Implications for Future Study}

This study leads on to an examination of the origins of schooling. Common wisdom would assume that the earliest schools — at least in the West - had their origin in the teaching/learning 
relationship between parents and children (Daniels 2001). But, as has been demonstrated (Lancy 2010), that relationship is so rare as to be almost ephemeral. On the other hand, an initial search for linkages between apprenticeship — as outlined in this article — and the earliest schools has been quite promising. For example, aspirant scribes in Mesopotamia worked away at their benches copying individual signs or syllables, and lists over and over from a model provided by the master. Once the clay tablet had been filled, it was inspected, errors noted then smoothed over to be re-used. "Advanced" students were set to copying "moralizing admonitions (Chiera 1966: 165)." Kramer has translated a personal account of an abused Sumerian student who complains about being caned by the teacher for every error and minor offense (Kramer 1963: 237-9). Change is little evident as schools in the late Middle Ages, similarly, featured mindless, repetitive work, religious instruction, strict discipline and regular punishment (Gies and Gies 1987:210-217).

Another promising strand of evidence comes from studies of schools newly introduced in indigenous communities. Here too we see pupils contractually engaged with a figure of towering authority — the western-educated and sophisticated teacher. They participate in menial work around the school and in the teacher's garden. In the classroom aping the teacher is the preferred form of instruction. Teaching per se is scarce while corporal punishment and verbal abuse are common (Lancy 1975). In Guinea the teachers' motto is: "Il faut suffrir pour apprendre (to learn one must suffer)" (Anderson-Levitt 2005:988). Classrooms and the inherent pedagogywell into the modern era - may have more closely resembled the iron-working, ceramic and textile workshops where apprentices toil to learn than the informal domestic settings in the village where children "pick up" many crafts ${ }^{9}$. 
Table 1 Cases Examined in the Survey

\begin{tabular}{|c|c|c|c|}
\hline Craft & Informal Process & Apprenticeship & Aprntshp General \\
\hline Pottery & $\begin{array}{l}\text { Bowser and Patton } 2008 \\
\text { (Amazonia) Crown } 2002 \\
\text { (US SW) De Lucia } 2010 \\
\text { (MesoAm) Gosselain } 2008 \\
\text { (W. Africa) Silva } 2008 \\
\text { (Amazonia) Spindel } 1989 \\
\text { (W. Africa) Wallaert } 2001 \\
\text { (W. Africa) }\end{array}$ & $\begin{array}{l}\text { Goody } 2006 \text { (W. } \\
\text { Africa) Singleton } \\
1989 \text { (Japan) } \\
\text { Wallaert 2008 (W. } \\
\text { Africa) Fowler } \\
1977 \text { (N. Am) }\end{array}$ & $\begin{array}{l}\text { Alexandre-Bidon \& Lett } \\
1999 \text { (Medieval Europe) } \\
\text { Barron } 2007 \text { (Mdvl } \\
\text { Europe) DeCoker } 1998 \\
\text { (Japan) De Munck and } \\
\text { Soly } 2007 \text { (16 }{ }^{\text {th }} \text { c. } \\
\text { Europe) Gies and Gies } \\
1987 \text { (Mdvl. Europe) } \\
\text { Golden } 2003 \text { (Anc. } \\
\text { Greece) Herzfeld } 1995 \\
\text { (Greece) Marguerat } 2000 \\
\text { (W. Africa) Mitterauer } \\
\text { and Sieder } 1997 \text { (17 } 7^{\text {th }}- \\
18^{\text {th }} \text { c.Europe) Mortimer } \\
\text { and Krüguer 2000 } \\
\text { (Europe) Rawson } 2003 \\
\text { (Anc. Rome) Stella } 2000 \\
\text { (Historic Europe) Lloyd } \\
1953 \text { (W. Africa) Peil } \\
1970 \text { (W. Africa) }\end{array}$ \\
\hline Stone Work & $\begin{array}{l}\text { Baxter 2005 } \\
\text { (Prehistory) Dawe } 1997 \\
\text { (N. Am) Sternke } 2010 \\
\text { (Neolithic Ireland) }\end{array}$ & $\begin{array}{l}\text { Roux, et al } 1995 \\
\text { (India) Stout } 2002 \\
\text { (New Guinea) }\end{array}$ & \\
\hline Weaving & $\begin{array}{l}\text { Bolin } 2006 \text { (Andes) } \\
\text { Campbell } 1964 \text { (Europe) } \\
\text { Greenfield } 2004 \text { (Mexico) } \\
\text { Huang } 2009 \text { (Iran) Laczko } \\
1979 \text { (Andes) MacKenzie } \\
1991 \text { (New Guinea) Pope-- } \\
\text { Edwards } 2005 \text { (India) } \\
\text { Reichard } 1934 \text { (US SW) } \\
\text { Tehrani and Collard 2009 } \\
\text { (Iran) }\end{array}$ & $\begin{array}{l}\text { Aronson1989 (W. } \\
\text { Africa) Defenbaugh } \\
1989 \text { (W. Africa) } \\
\text { Dilley } 1989 \text { (W. } \\
\text { Africa) Friedl } 1997 \\
\text { (Iran) Steidl } 2007 \\
\left(17^{\text {th }}-18^{\text {th }} \text { c.Europe) }\right. \\
\text { Tanon } 1994 \text { (W. } \\
\text { Africa) }\end{array}$ & \\
\hline Blacksmith & & $\begin{array}{l}\text { Coy } 1989 \text { (W. } \\
\text { Africa) Lancy } 1980 \\
\text { (W. Africa) } \\
\text { McNaughton } 1988 \\
\text { (W. Africa) Obidi } \\
\text { 1995 (W. Africa) }\end{array}$ & \\
\hline Carving & $\begin{array}{l}\text { Chernela } 2008 \text { (Amazonia) } \\
\text { Wilbert } 1976 \text { (S. Am) }\end{array}$ & $\begin{array}{l}\text { Gladwin } 1970 \\
\text { (Micronesia) } \\
\text { Messenger 1973 }\end{array}$ & \\
\hline
\end{tabular}




\begin{tabular}{|c|c|c|}
\hline & & $\begin{array}{l}\text { (W. Africa) Cooper } \\
1989 \text { (E. Asia) }\end{array}$ \\
\hline Basketry & $\begin{array}{l}\text { Edel } 1996 \text { (E. Africa) } \\
\text { McClendon and Holland } \\
1979 \text { (N. Am) }\end{array}$ & $\begin{array}{l}\text { Pryor and Carr } \\
1995 \text { (N. Am) }\end{array}$ \\
\hline Painting & & Jordan 1998 (Japan) \\
\hline Construction & & $\begin{array}{l}\text { Marchand } 2001 \\
\text { (Yemen) }\end{array}$ \\
\hline Tailoring & & $\begin{array}{l}\text { Lave } 1982(\mathrm{~W} . \\
\text { Africa) }\end{array}$ \\
\hline $\begin{array}{l}\text { Non-Crafts } \\
\text { 1.Religious } \\
\text { Specialist } \\
\text { 2. Navigator } \\
\text { 3. Priest } \\
\text { 4. Griot }\end{array}$ & & $\begin{array}{l}\text { 1. Bledsoe and } \\
\text { Robey } 1986 \text { (W. } \\
\text { Africa) } \\
\text { 2. Gladwin } 1970 \\
\text { (Micronesia) } \\
\text { 3. Reichel- } \\
\text { Dolmatoff } 1976 \text { (S. } \\
\text { Am) 4. Ames } 1973 \\
\text { (W. Africa) }\end{array}$ \\
\hline
\end{tabular}




\section{Notes}

${ }^{1}$ An earlier version of this paper was given at the annual Society for the Study of Childhood in the Past (SSCIP) Conference: "Child Labour in the Past”, Cambridge, UK, October 2011

${ }^{2}$ http://www.yale.edu/hraf/collections.htm

${ }^{3}$ I am grateful to Annette Grove for research and editorial assistance and to AWR editor Michael Chibnik for his thorough and careful editorial work. Two anonymous reviewers also provided extremely helpful ideas and suggestions.

4 Unless noted otherwise (e.g. Neolithic Ireland), these cases are based on contemporary accounts. However, it is also clear that in many, if not most cases, the particular crafts are no longer in demand or have changed so radically that they no longer entail an apprenticeship. ${ }^{5}$ A limitation does arise from the geographic distribution of cases in the literature. West Africa, Japan and Latin America are relatively well represented, whereas the Pacific and Asia, generally, are sparsely represented.

${ }^{6}$ Bear in mind that the practice of transferring a child from its natal household to another is or was common in many societies. This may be referred to as fostering (Talle 2004) or circulating children (Leinaweaver 2008). Apprenticeship is only one of many reasons to move children from their natal home to a setting considered more conducive to their continued development.

${ }^{7}$ An interesting and possibly anomalous exception is found among Langda stone adze makers in the New Guinea Highlands. Because the male apprentices are near in age to the master the hierarchical relationship is less marked. The interaction is more informal, like that between a parent and child (Stout 2002:698; also Toth et al 1992).

${ }^{8}$ This is true for the non-craft apprenticeships listed in Table 1 as well. 


\section{References}

Alexandre-Bidon, Daniéle, and Lett, Didier. 1999. Children in the Middle Ages: Fifth-Fifteenth Centuries. Notre Dame: The University of Notre Dame Press.

Ames, David W. 1973. A Sociocultural View of Hausa Musical Activity. In The Traditional Artist in African Societies. Warren L. d'Azevedo, Ed. Pp. 128-161. BloomingtonIndiana University Press.

Anderson-Levitt, Katherine M. 2005. The Schoolyard Gate: Schooling and Childhood in Global Perspective. Journal of Social History 38(4), 987-1006.

Aronson, Lisa. 1989. To Weave or Not To Weave: Apprenticeship Rules among the Akwete Igbo of Nigeria and the Baule of the Ivory Coast. In Apprenticeship: From Theory to Method and Back Again. Michael W. Coy, Ed. Pp. 149-162. Albany: SUNY Press. 
Barron, Caroline M. 2007. The Child in Medieval London: The Legal Evidence. In Essays on Medieval Childhood:Responses to Recent Debate. Joel T. Rosenthal, Ed. Pp. 40-53. Donington, UK: Shaun Tyas.

Baxter, Jane E. 2005. The Archaeology of Childhood. New York: Altamira Press.

Beier, A. L. 1978. Social Problems in Elizabethan London. Journal of Interdisciplinary History, 9: 203-221.

Binkley, David A. 2006. From Grasshoppers to Babende: The Socialization of Southern Kuba Boys to Masquerade. In Playful Performers: African Children's Masquerades. Simon Ottenberg and David A. Binkley, Eds. Pp.105-115. London: Transaction Publishers.

Bledsoe, Caroline H., and Robey, Kenneth M. 1986. Arabic Literacy and Secrecy among the Mende of Sierra Leone. Man, 21(2):202-226.

Bolin, Inge. 2006. Growing Up in a Culture of Respect: Child Rearing in Highland Peru. Austin:University of Texas Press.

Bowser, Brenda J., and Patton, John Q. 2008. Learning and Transmission of Pottery Style: Women's Life Histories and Communities of Practice in the Ecuadorian Amazon. In Breaking Down Boundaries: Anthropological Approaches to Cultural Transmission, Learning and Material Culture. Miriam T. Stark, Brenda J. Bowser, and Lee Horne, Eds. Pp. 105-129. Tucson:University of Arizona Press. 
Bradley, Keith R. 1991. Discovering the Roman Family: Studies in Roman Social History. Oxford: Oxford University Press.

Campbell, John K. 1964. Honour, Family, and Patronage: A Study of Institutions and Moral Values in a Greek Mountain Community. Oxford: Clarendon Press.

Chernela, Janet. 2008. Translating Ideologies: Tangible Meaning and Spatial Politics in the Northwest Amazon of Brazil. In Cultural Transmission and Material Culture: Breaking Down Boundaries. Miriam T. Start, Brenda J. Bowser, and Lee Horne, Eds. Pp. 130-149. Tucson: The University of Arizona Press.

Chiera, Edward 1938/1966. They Wrote on Clay: The Babylonian Tablets Speak Today. Chicago, IL: University of Chicago Press.

Cooper, Eugene 1989. Apprenticeship as Field Method: Lesson from Hong Kong. In Apprenticeship: From Theory to Method and Back Again. Michael W. Coy, Ed. Pp. 137-148. Albany: SUNY Press.

Coy, Michael W. (Ed.) 1989a. Apprenticeship: From Theory to Method and Back Again. Albany: SUNY Press.

Coy, Michael W. 1989b. Introduction. In Apprenticeship: From Theory to Method and Back Again. Michael W. Coy, Ed. Pp. xi-xv. Albany: SUNY Press. 
Coy, Michael W. 1989c. From Theory. In Apprenticeship: From Theory to Method and Back Again. Michael W. Coy, Ed. Pp. 1-12. Albany: SUNY Press.

Coy, Michael W. 1989d. Being What We Pretend to Be: The Usefulness of Apprenticeship as a Field Method. In Apprenticeship: From Theory to Method and Back Again. Michael W. Coy, Ed. Pp. 115-135. Albany: SUNY Press.

Crown, Patricia L. 2002. Learning and Teaching in the Prehispanic American Southwest. In Children in the Prehistoric Puebloan Southwest. Katheryn A. Kamp, Ed. Pp. 108-124, Salt Lake City: The University of Utah Press.

Crown, Patricia. 1999. Socialization in American Southwest pottery decoration. In Pottery and People: A Dynamic Interaction. James M. Skibo and Gary M. Feinman Eds. Pp. 25-43. Salt Lake City, UT: University of Utah Press.

Daniels, Harry 2001. Vygotsky and Pedagogy. London: Routledge.

Dawe, Bob. 1997. Tiny Arrowheads: Toys in the Toolkit. Plains Anthropology, 42161:303-318.

DeCoker, Gary. 1998. Seven Characteristics of a Traditional Japanese Approach to Learning. In Learning in Likely Places: Varieties of Apprenticeship in Japan. John Singleton, Ed. Pp. 68-84. Cambridge: Cambridge University Press. 
Defenbaugh, Linda. 1989. Hausa Weaving: Surviving Amid the Paradoxes. In Apprenticeship: From Theory to Method and Back Again. Michael W. Coy, Ed. Pp. 163-179. Albany: SUNY Press.

De Lucia, Kristin. 2010. A Child's House: Social Memory, Identity, and the Construction of Childhood in Early Postclassic Mexican Households. American Anthropologist, 1124:607-624.

De Munck, Bert, and Soly, Hugo. 2007. Learning on the Shop Floor. In Learning on the Shop Floor: Historical Perspectives on Apprenticeship. Bert De Munck, Steven L. Kaplan, and Hugo Soly, Eds. Pp. 3-32. Oxford: Berghahn Books.

Dilley, Roy M. 1989. Secrets and skills: Apprenticeship among Tukolor weavers. In Apprenticeship: From Theory to Method and Back Again. Michael W. Coy, Ed. Pp. 181-198. Albany: SUNY Press.

Edel, May M. 1996[1957]. The Chiga of Uganda, $2^{\text {nd }}$ ed. New Brunswick, NJ: Transaction Publishers.

Ferguson, Jeffrey R. 2003. An Experimental Task of the Conservation of Raw Material in Flint Knapping Skill Acquisition. Lithic Technology, 282:113-131.

Fowler, Carol. 1977. Daisy Hooee Nampeyo: The Story of an American Indian. Minneapolis, MN: Dillon Press. 
Friedl, Erika. 1997. Children of Deh Koh: Young Life in an Iranian Village. Syracuse: Syracuse University Press.

Gamst, Frederick C. 1989. The Railroad Apprentice and the "Rules": Historic Roots and Contemporary Practices. In Apprenticeship: From Theory to Method and Back Again. Michael W. Coy, Ed. Pp. 65-86. Albany: SUNY Press.

Graves, Bennie 1989. Informal Aspects of Apprenticeship in Selected American Occupations. In Apprenticeship: From Theory to Method and Back Again. Michael W. Coy, Ed. Pp. 51-64. Albany: SUNY Press.

Ghosh, Amitav. 1992. An Antique Land. London: Granta Books.

Gies, Frances, and Gies, Joseph. 1987. Marriage and the Family in the Middle Ages. New York: Harper and Row.

Gladwin, Thomas. 1970. East is a Big Bird: Navigation and Logic on Puluwat Atoll. Cambridge, MA: Harvard University Press.

Goffman, Erving 1961. Asylums: Essays on the Social Situation of Mental Patients and Other Inmates. New York: Anchor Books.

Golden, Mark. 2003. Childhood in Ancient Greece. In Coming of Age in Ancient Greece. Jennifer Neils and John H. Oakley, Eds. Pp 13-29. New Haven: Yale University Press. 
Goody, Ester N. 2006. Dynamics of the Emergence of Sociocultural Institutional Practices. In Technology, Literacy, and the Evolution of Society. David R. Olson and Michael Cole, Eds. Pp. 241-264. Mahwah: Erlbaum.

Gosselain, Olivier P. 2008. Mother Bella Was Not a Bella: Inherited and Transformed Traditions in Southwestern Niger. In Cultural Transmission and Material Culture: Breaking Down Boundaries. Miriam T. Start, Brenda J. Bowser, and Lee Horne, Eds. Pp. 150-177. Tucson: The University of Arizona Press.

Greenfield, Patricia Marks. 2004. Weaving Generations Together: Evolving Creativity in the Maya of Chiapas. Santa Fe: School of American Research Press.

Greenfield, Patricia M. and Lave, Jean 1982. Cognitive Aspects of Informal Education. In Cultural Perspectives on Child Development. Wagner, Daniel A. and Stevenson, Harold W. Eds. Pp181-207. San Francisco,CA: W.H. Freeman

Gruber, Hans G., and Heinz Mandl. 2001. Apprenticeship and School Learning. In International Encyclopedia of Social and Behavioral Sciences. Neil J. Smelser and Paul B. Baltes, Eds. Pp. 601644. New York: Elsevier,

Herzfeld, Michael. 1995. It Takes One to Know One: Collective Resentment and Mutual Recognition among Greeks in Local and Global Contexts. In Counterworks: Managing the Diversity of Knowledge. Richard Fardon. Ed. Pp. 124-142. London: Routledge. 
Huang, Julia. 2009. Tribeswomen of Iran: Weaving Memories among Qashqa'i Nomads. London: I.B. Tauris.

Jenness, Diamond. 1922. The Life of the Copper Eskimos. Report of the Canadian Arctic Expedition, 1913-18, vol. 12A. Ottawa, Canada.

Jordan, Brenda G. 1998. Education in the Kanõ School in Nineteenth-century Japan: Questions about the Copybook Method. In Learning in Likely Places: Varieties of Apprenticeship in Japan. John Singleton, Ed. Pp. 45-67. New York: Cambridge University Press.

Kaplan, Steven. 2007. Reconsidering Apprenticeship: Afterthoughts. In On the Shop Floor: Historical Perspectives on Apprenticeship Learning. Bert De Munck, Steven L. Kaplan, and Hugo Soly, Eds. Pp. 203-218. New York: Berghahn Books.

Köhler, Iris. 2012. Learning and Children's Work in a Pottery Making Environment in Northern Côte d'Ivoire. In African Children at Work: Working and Learning in Growing Up. Gerd Spittler and Michael Bourdillion, Eds. Pp. 113-142. Berlin: Lit Verlag.

Kramer, Samuel N. 1963. The Sumerians: Their History, Culture, and Character. Chicago, IL: The University of Chicago Press. 
Laczko, Gina. 1979. The weaver: The Araucanians of Chile. In The Ancestors: Native Artisans of The Americas. Anna C. Roosevelt and James Smith Eds. Pp 130-157. New York: Museum of the American Indian.

Lancy, David F. 1975. The Social Organization of Learning: Initiation Rituals and Public Schools. Human Organization. 34: 371-380.

Lancy, David F. 1980. Becoming a Blacksmith in Gbarngasuakwelle. In Anthropology and Education Quarterly, 11:266-274.

.1996. Playing on the Mother Ground: Cultural Routines for Children's Development. New York: Guilford.

. 2008. The Anthropology of Childhood: Cherubs, Chattel, Changelings. Cambridge:

Cambridge University Press.

. 2010. Learning "From Nobody:" The Limited Role of Teaching in Folk Models of Children's Development. Childhood in the Past, 3:79-106.

. 2012. The chore curriculum. In African Children at Work: Working and Learning in Growing Up. Gerd Spittler and Michael Bourdillion, Eds. Pp. 23-57. Berlin: Lit Verlag.

Lancy, David F., and Grove, M. Annette. 2011. "Getting Noticed": Middle childhood in CrossCultural Perspective. Human Nature, 22:281-302. 
Lave, Jean. 1982. A Comparative Approach to Educational Forms and Learning Processes. Anthropology and Education Quarterly, 132:181-187.

Leinaweaver, Jessaca. 2008. Improving oneself: Young people getting ahead in the Peruvian Andes. Special Issue on Youth, Culture, and Politics in Latin America. Latin American Perspectives, 354:60-78.

Lipsett-Rivera, Sonya. 2002. Model Children and Models for Children in Early Mexico. In Minor Omissions: Children in Latin American History and Society. Tobias Hecht, Ed. Pp. 52-71. Madison: University of Wisconsin Press.

Lloyd, Peter 1953. Craft Organization in Yoruba Towns. Africa 23: 30-44.

McClendon, Sally and Holland, Brenda S. 1979. The basketmaker: The Pomoans of California. In The Ancestors: Native Artisans of The Americas. Anna C. Roosevelt and James Smith Eds. Pp 102129. New York: Museum of the American Indian.

MacDonald, Katherine. 2007. Cross-Cultural Comparison of Learning in Human Hunting: Implication for Life History Evolution. Human Nature, 18:386-402.

MacKenzie, Maureen Anne. 1991. Androgynous Objects: String Bags and Gender in Central New Guinea. Reading: Harwood. 
Marchand, Trevor H. J. 2001. Minaret Building and Apprenticeship in Yemen. Richmond: Curzon Press.

Marguerat, Yves. 2000. The Exploitation of Apprentices in Togo. In The Exploited Child. Bernard Schlemmer, Ed. Pp 239-247. New York: Zed Books.

McNaughton, Peter R. 1988. The Mande Blacksmiths: Knowledge, Power and Art in West Africa. Bloomington: Indiana University Press.

Messenger, John C. 1973. The Carver in Anang society. In The Traditional Artist in African Societies. Warren L. d'Azevedo, Ed. Pp. 101-127. Bloomington, IN: Indiana University Press.

Mitterauer, Michael, and Sieder, Reinhard. 1997. The European Family: Patriarchy to Partnership from the Middle Ages to the Present. Chicago: University of Chicago Press.

Moeran, Brian 1984. Lost Innocence: Folk Craft Potters of Onta, Japan. Berkeley, CA: University of California Press.

Moeran, Brian 1997. Folk Art Potters of Japan: Beyond an Anthropology of Aesthetics. London: Curzon Press. 
Mortimer, Jeylan T. and Krüguer, Helga 2000. Pathways from School to Work in Germany and the United States. In Handbook for the Sociology of Education. Maureen T. Hallinan. Ed. Pp. 475-497. New York: Plenum.

Obidi, S. S. 1995. Skill Acquisition through Indigenous Apprenticeship: A Case Study of the Yoruba Blacksmith in Nigeria. Comparative Education, 313:369-383.

Park, Robert W. 2006. Growing up North: Exploring the Archaeology of Childhood in the Thule and Dorset Cultures of Arctic Canada. Archeological Papers of the American Anthropological Association, 15:53-64.

Peil, Margaret 1970. The Apprenticeship System in Accra. Africa 40: 137-150.

Pope-Edwards, Caroline. 2005. Children's Play in Cross-Cultural Perspective: A New Look at the Six Culture Study. In Play: An Interdisciplinary Synthesis. Felicia F. McMahon, Don E. Lytle, and Benjamin S. Smith, Eds. Pp. 81-96. Lanham, MD: University Press of America.

Pryor, John, and Carr, Christopher. 1995. Basketry of Northern California Indians: Interpreting Style Hierarchies. In Style, Society, and Person: Archaeological and Ethnological Perspectives. Christopher Carr and Jill E. Neitzel, Eds. Pp. 259-296. New York: Plenum.

Rawson, Beryl. 2003. Children and Childhood in Roman Italy. Oxford: Oxford University Press.

Reichard, Gladys. 1934. Spider Woman: A Story of Navaho Weavers and Chanters. New York: Macmillan. 
Reichel-Dolmatoff, Gerardo. 1976. Training for the Priesthood among the Kogi of Columbia. In Enculturation in Latin America. Johannes Wilbert, Ed. Pp. 265-288. Los Angeles, CA: UCLA Latin American Center Publications.

Roux, Valentine, Brill, Blandine, and Dietrich, Gilles. 1995. Skills and Learning Difficulties Involved in Stone Knapping: The Case of Stone-Bead Knapping in Khambhat, India. World Archaeology, 27(1):63-87.

Sharratt, Nicola 2008. Gender and weaving in Peruvian villages. Paper presented at Spinning Tales Colloquium, School of English, Center for Gender, Sexuality and Writing, University of Kent, England, January 23rd.

Silva, Fabíola A. 2008. Ceramic Technology of the Asurini do Xingu, Brazil: An Ethnoarchaeological Study of Artifact Variability. Journal of Archaeological Method and Theory. $15: 217-265$.

Singleton, John. 1989. Japanese folkcraft Pottery Apprenticeship: Cultural Patterns of an Educational Institution. In Apprenticeship: From Theory to Method and Back Again. Michael W. Coy, Ed. Pp. 13-30. Albany: SUNY Press. , Ed. 1998a. Learning in Likely Places: Varieties of Apprenticeship in Japan. Cambridge: Cambridge University Press. 
, 1998b. Situated Learning in Japan: Our Educational Analysis. In Learning in Likely

Places: Varieties of Apprenticeship in Japan. John Singleton, Ed., Pp 3-19. Cambridge:

Cambridge University Press.

Smith, Patricia E. 2006. Children and Ceramic Innovation: A Study in the Archaeology of Children. Archeological Papers of the American Anthropological Association, 15:65-76.

Spindel, Carol. 1989. Kpeenbele Senufo Potters. African Arts, 222:66-73 and 103.

Steidl, Annemarie. 2007. Silk Weaver and Purse Maker Apprentices in Eighteenth- and NineteenthCentury Vienna. In Learning on the Shop Floor: Historical Perspectives on Apprenticeship. Bert De Munck, Steven L. Kaplan, and Hugo Soly, Eds. Pp. 133-157. Oxford: Berghahn Books.

Stella, Alessandro. 2000. Introduction: A history of exploited children in Europe. In The Exploited Child. Bernard Schlemmer, Ed. Pp. 21-38. New York: Zed Books.

Sternke, Farina. 2010. From Boy to Man: 'Rights' of Passage and the Lithic Assemblage from a Neolithic Mound in Tullahedy, Co. Tipperary. In Creative Minds. Proceedings of the Public Seminar on Archaeological Discoveries on National Road Schemes, August 2009. Archaeology and the National Roads Authority Monograph Series No. 7. Michale Stanley, Ed Danaher, and James Eogan, Eds. Pp. 1-14. Dublin : National Roads Authority. 
Stout, Dietrich. 2002. Skill and Cognition in Stone Tool Production: An Ethnographic Case Study from Irian Jaya. Current Anthropology, 43:693-715.

Talle, Aud. 2004. Adoption Practices among the Pastoral Massai of East Africa. In Cross Cultural Approaches to Adoption. Fiona Bowie, Ed. Pp. 64-78. London: Routledge.

Tanon, Fabienne. 1994. A Cultural View on Planning: The Case of Weaving in Ivory Coast. Tillburg, Netherlands: Tilburg University Press.

Tehrani, Jamshid J., and Collard, Mark. 2009. On the Relationship between Interindividual Cultural Transmission and Population-Level Cultural Diversity: A Case Study of Weaving in Iranian Tribal Populations. Evolution and Human Behavior, 30:286-300.

Toth, Nicholas, Clark, Desmond, and Ligabue, Giancarlo. 1992. The Last Stone Ax Makers. Scientific American, 267(1):88-93.

Voget, Fred W. 1975. A History of Ethnology. New York: Holt, Rinehart and Winston.

Wallaert, Hélène. 2001. Learning How to Make the Right Pots: Apprenticeship Strategies and Material Culture, a Case Study in Handmade Pottery from Cameroon. Journal of Anthropological Research, 57:471-493. 
. 2008. The Way of the Potter's Mother: Apprenticeship Strategies among Dii Potters from Cameroon, West Africa. In Cultural Transmission and Material Culture: Breaking Down Boundaries.

Miriam T. Start, Brenda J. Bowser, and Lee Horne, Eds. Pp. 178-198. Tucson: The University of Arizona Press.

Wilbert, Johannes. 1976. To Become a Maker of Canoes: An Essay in Warao enculturation. In Enculturation in Latin America. Johannes Wilbert, Ed. Pp. 303-358. Los Angeles: UCLA Latin American Center Publications.

${ }^{9}$ One reader of an earlier draft of the manuscript felt that a good case could be made that the pursuit of a Ph.D. had many, if not most, of the characteristics of an apprenticeship (Elisa Sobo, personal communication 4.23.12) 